\title{
Is the use of entomopathogenic fungi a viable option for the control of Red Palm Weevil?
}

\author{
M. El Bouhssini ${ }^{1}$, A.N. Trissi ${ }^{2}$ and Z. Kadour ${ }^{2}$ \\ (1) International Center for Agricultural Research in the Dry Areas (ICARDA), P.O. Box 6299, Rabat Institute, Morocco, \\ email: M.Bohssini@cgiar.org; (2) Faculty of Agriculture, Aleppo University, Aleppo, Syria.
}

\begin{abstract}
El Bouhssini. M., A.N. Trissi and Z. Kadour. 2019. Is the use of entomopathogenic fungi a viable option for the control of Red Palm Weevil?. Arab Journal of Plant Protection, 37(2): 200-202.

During the period 2010-2014, a survey of entomopathogenic fungi of red palm weevil (RPW) in the coastal areas of Syria were characterized and their efficacy against RPW was investigated. In addition, the naturally existing endophytes in palm trees were investigated. Promising results for the control of RPW were obtained under semi-field conditions using B. bassiana isolates. The big challenge for the different researchers working with entomopathogenic fungi is to have this type of high efficacy in the field where generally temperature is high and relative humidity is low. The potential use of $B$. bassiana endophytes was also discussed.

Keywords: Red pam weevil, date palm, entomopathogenic fungi, endophytes.
\end{abstract}

\section{Introduction}

Red palm weevil (RPW), Rhynchophorus ferrugineus (Olivier), (Coleoptera: Curculionidae) is one of the most destructive pests of palm trees worldwide (Dembilio and Jaques, 2015; Faleiro et al., 2016). Several management strategies for the control of RPW have been developed and tried in different parts of the world. However, biological control is the component of integrated pest management (IPM), which has not been fully explored for the control of this pest. Entomopathogenic fungi (EPF) have been found to be promising bioagents in IPM programs against several insect pests. EPF have also been found as endophytes in a diversity of crops (Vega et al., 2009). Colonization of date palm by B. bassiana and Lecanicillium spp. enhances plant defence and stress response (Gómez-Vidal et al., 2009), and provides plant growth promotion benefits (Jaber and Enkerli, 2016). Using endophytic isolates, in some cases, have resulted in complete control of the target pest (QuesadaMoraga et al., 2006). However, endophytes are still poorly explored as a management option for systemic protection of palms against $R$. ferrugineus.

\section{Survey of RPW Entomopathogenic Fungi}

A survey of entomopathogenic fungi of RPW in the coastal areas of Syria in 2010, 2011 and 2012 seasons was carried out. The collected isolated were characterized and their efficacy against RPW was investigated. In 2014, another survey was conducted to investigate the naturally existing endophytes in palm trees. Healthy peripheral leaves from 515-year-old palms were cut, surface sterilized and assessed for colonization by EPF. More than 4230 samples of different stages of RPW were collected. These insects were placed in plastic containers and killed by freezing. Dead insects were surface sterilized, incubated for 2 weeks to observe fungal outgrowth and then were identified. Twelve fungal isolates of Beauveria bassiana, and one isolate of Lecanicillium sp. were obtained.

\section{Characterization of $\boldsymbol{B}$. bassiana Isolates}

The characterization of $B$. bassiana isolates showed that the best fungal growth, in vitro, was at $25^{\circ} \mathrm{C}$, and the higher productivity of conidial spores was at $20^{\circ} \mathrm{C}$. The pathogenicity test of three B. bassiana isolates (BBS, RPWSL 5 and GHA) against red palm weevil adults showed highest insect mortality of $93.75 \%$ and $100 \%$ after 14 days of application with the RPWSL 5 isolate when concentration $1 \times 10^{7}$ and $1 \times 10^{8}$ conidia $\mathrm{ml}^{-1}$ were used, respectively. Moreover, The $\mathrm{LC}_{50}$ values varied from $2 \times 10^{5}$ to $1 \times 10^{9}$ conidia $\mathrm{ml}^{-1}$, depending on the isolate. The lowest $\mathrm{LC}_{50}$ was $2.12 \times 10^{5}\left(1.3 \times 10^{5}-3.2 \times 10^{5}\right)$ conidia $\mathrm{ml}^{-1}$ when insect was treated with RPWSL 5 compared with $7.1 \times 10^{8}\left(5.1 \times 10^{8}-1\right.$ $\times 10^{9}$ ) conidia $\mathrm{ml}^{-1}$ when GHA (commercial isolate) was used. The $\mathrm{LT}_{50}$ values varied from 3.5 to 28.6 days, depending on the isolate. The shortest $\mathrm{LT}_{50}$ value (3.5 days) was obtained with RPWSL 5 at $1 \times 10^{7}$ conidia $\mathrm{ml}^{-1}$. The longest $\mathrm{LT}_{50}$ (28.64 days) was obtained with BBS at $1 \times 10^{7}$ conidia $\mathrm{ml}^{-1}$. Results obtained showed that there are entomopathogenic fungal isolates effective against the different stages of the RPW under laboratory conditions. Similarly, many laboratory studies showed that EPF caused high mortality (80-100\%) of RPW larvae and adults (Francardi et al., 2013; Gindin et al., 2006; Merghem, 2011). Promising results for the control of RPW were also obtained under semi-field conditions using $B$. bassiana isolates (Dembilio et al., 2010; El-Sufty et al., 2009), Lecanicillium (Verticillium) lecanii (Sabbour and Solieman, 2014) and Isaria fumosorosea (Sabbour and Abdel-Raheem, 2014). The big challenge for the different researchers working with entomopathogenic fungi is to have this type of high efficacy in the field where generally temperature is high and relative humidity is low. In addition, because the larvae are hidden

http://dx.doi.org/10.22268/AJPP-037.2.200202

(C) 2019 Arab Society for Plant Protection الجمعية العربية لوقاية النبات 
within the host, it may be difficult to get them infected by EPF. Other researchers tried using attract and infect strategy of RPW adult (Dembilio et al., 2010; Yasin et al., 2017).

\section{Characterization of $\boldsymbol{B}$. bassiana Endophytes}

Three $B$. bassiana entophytic isolates were isolated from healthy palm trees from the coastal area of Syria. Similarly, (Gómez-Vidal et al., 2006) reported the potential of $B$. bassiana, L. dimorphum and L. psalliotae as endophytes in the young and adult date palm petioles; fungi were detected microscopically inside the parenchyma and sparsely distributed within vascular tissue without the date palm showing any negative effect. Gomez-Vidal et al. (2009), hypothesized that entomopathogenic fungi growing endophytically in palms modulate plant defence and could promote palm growth. The three B. bassiana endophytic isolates we identified have not yet been tested for their efficacy against RPW. However, we do believe that more research focus should be placed on endophytic isolates, as they seem to present better potential as biocontrol agents for RPW: delivery systems to the target pest should be easier and might not be exposed to the same harsh climatic conditions compared to entomopathogenic fungi.

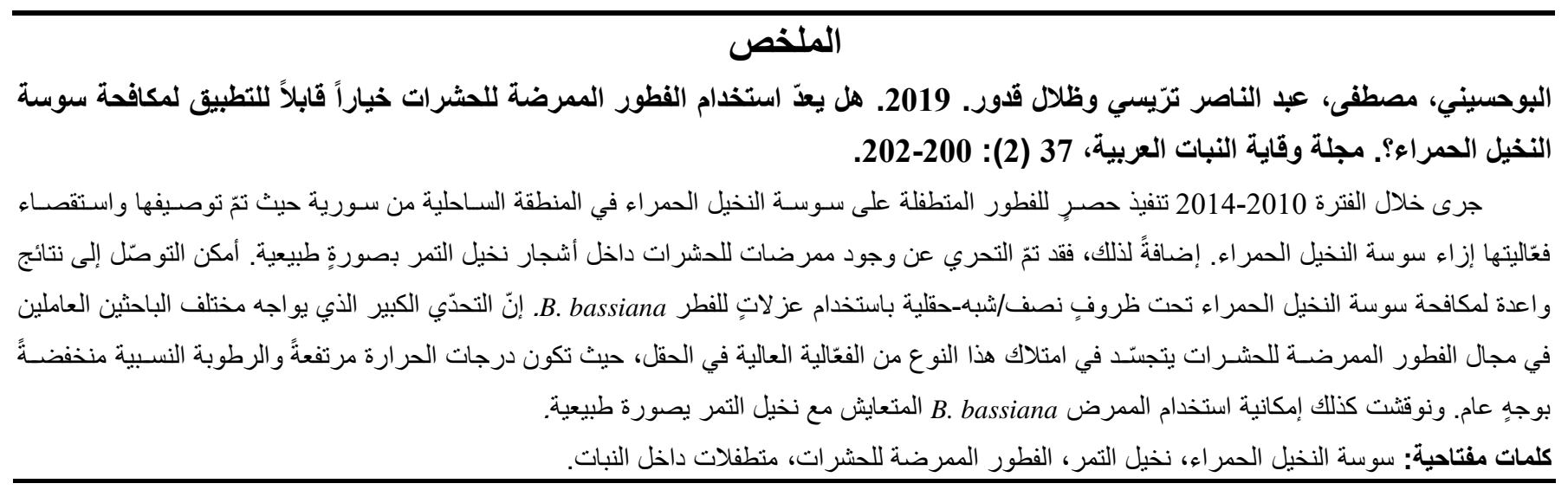

\section{References}

Dembilio Ó. and J.A. Jaques. 2015. Biology and management of red palm weevil. Pages 13-36. In: Sustainable Pest Management in Date Palm: Current Status and Emerging Challenges. W. Wakil, J.R. Faleiro and T.A. Miller (eds.). Springer International Publishing, Switzerland. https://doi.org/10.1007/978-3-319-24397-9

Dembilio, Ó., E. Quesada-Moraga, C. Santiago-Álvarez and J.A. Jacas. 2010. Biocontrol potential of an indigenous strain of the entomopathogenic fungus Beauveria bassiana (Ascomycota; Hypocreales) against the red palm weevil, Rhynchophorus ferrugineus (Coleoptera: Curculionidae). Journal of Invertebrate Pathology, 104: 214-221. https://doi.org/10.1016/j.jip.2010.04.006

El-Sufty, R., S.A. Al-Awash, S. Al-Bgham, A.S. Shahdad, and A.H. Al-Bathra. 2009. Pathogenicity of the fungus Beauveria bassiana (Bals.) Vuill to the red palm weevil, Rhynchophorus ferrugineus (Oliv.) (Col.: Curculionidae) under laboratory and field conditions. Egyptian Journal of Biological Pest Control, 19: 8185.

Faleiro, J.R., J.A. Jaques, D. Carrillo, R. Giblin-Davis, C.M. Mannion, E. Peña-Rojas and J.E., Peña. 2016. Integrated pest management (IPM) of palm pests. Pages 439-497. In: Integrated Pest Management in the Tropics. D.P. Abrol (ed.). New India Publishing Agency, New Delhi, India.

Francardi, V., C. Benventi, G.P. Barzanti and P.F. Rovers. 2013. Autocontamination trap with entomopathogenic fungi: A possible strategy in the control of Rhynchophorus ferrugineus (Olivier) (Coleoptera Curculionidae). Journal of Zoology, 96: 57-67.

Gindin, G., S. Levski, I. Glazer and V. Soroker. 2006. Evaluation of the entomopathogenic fungi Metarhizium anisopliae and Beauveria bassiana against the red palm weevil Rhynchophorus ferrugineus. Phytoparasitica, 34: 370-379. https://doi.org/10.1007/bf02981024

Gómez-Vidal, S., L.V. Lopez-Llorca, H. B. Jansson and J. Salinas. 2006. Endophytic colonization of date palm (Phoenix dactylifera L.) leaves by entomopathogenic fungi. Micron, 37: 624-632. https://doi.org/10.1016/j.micron.2006.02.003

Gómez-Vidal, S., J. Salinas, M. Tena and L.V. LopezLlorca. 2009. Proteomic analysis of date palm (Phoenix dactylifera L.) responses to endophytic colonization by entomopathogenic fungi. Electrophoresis, 30: 2996-3005. https://doi.org/10.1002/elps.200900192

Jaber, L.R. and J. Enkerli. 2016. Fungal entomopathogens as endophytes: can they promote plant growth? Biocontrol Science and Technology, 27: 28-41. https://doi.org/10.1080/09583157.2016.1243227

Merghem, A. 2011. Susceptibility of the red palm weevil, Rhynchophorus ferrugineus (Olivier) to the green muscardine fungus, Metarhizium anisopliae (Metsch.) in the laboratory and in palm tree orchards. Egyptian Journal of Biological Pest Control, 21: 179-183. 
Quesada-Moraga, E., J.A. Carrasco-Díaz and C. Santiago-Álvarez. 2006. Insecticidal and antifeedant activities of proteins secreted by entomopathogenic fungi against Spodoptera littoralis (Lepidoptera, Noctuidae). Journal of Applied Entomology, 130: 442452.

https://doi.org/10.1111/j.1439-0418.2006.01079.x

Sabbour, M. and M. Abdel-Raheem. 2014. Evaluations of Isaria fumosorosea isolates against the Red Palm Weevil Rhynchophorus ferrugineus under laboratory and field conditions. Current Science International, 3: 179-185. https://doi.org/10.13140/RG.2.1.2503.4085

Sabbour, M.M. and N.Y. Solieman. 2014. Preliminary Investigations into the Biological Control of Red Palm Weevil Rhynchophorus ferrugineus by using three isolates of the fungus Lecanicillium (Verticillium) lecanii in Egypt. International Journal of Science and Research, 3: 2016-2066.

https://doi.org/10.13140/RG.2.1.1782.5121

Vega, F.E., M.S. Goettel, M. Blackwell, D. Chandler, M.A. Jackson, S. Keller, M. Koike, M. Maniania, A. onzon, B.H. Ownley, J.K. Pell, D.E.N. Rangel and H.E. Roy. 2009. Fungal entomopathogens: new insights on their ecology. Fungal Ecology, 2: 149-159. https://doi.org/10.1016/j.funeco.2009.05.001

Yasin, M., W. Wakil, H.A.F. El-Shafie, G.O. Bedford and T.A. Miller. 2017. Potential role of microbial pathogens in control of red palm weevil (Rhynchophorus ferrugineus) - A Review. Entomological Research, 47: 219-234. https://doi.org/10.1111/1748-5967.1222 